\title{
Book Reviews Part 1
}

\section{Recommended reading}

September is one of the times of year when we make resolutions. Although we never talk about them in the way we talk of New Year's Resolutions, many of us do resolve to get into good habits in the autumn, after a break from routines over the summer. Perhaps one routine you want to develop further is that relating to your prayer life. In this section of the book reviews, I am recommending two different resources that I personally have found helpful in developing my relationship with Jesus over the past few months.

\section{Voke, C. (2013). Prayers of Great Traditions: A Daily Office. London: Bloomsbury.}

I have really benefitted from using this book. It is not one you sit down to read, but one you use to shape your prayers. There are twenty-eight chapters, each with prayers for the Morning and Evening Office. The first two chapters are based on Scripture, and the remaining twenty-six are based on the prayers of well-known individuals or Christian groups. Individuals include John Chrysostom, Julian of Norwich, Martin Luther, William Laud, John Wesley and Karl Barth. Groups include Benedictine and Franciscan prayer. The Morning Office is structured with preparation; an invitation to read a psalm (of which several are included in Voke's own translation); some readings; prayers structured around four foci (self, community and neighbours, church and the mission of Christ, and those in authority and the needs of the world); and a conclusion. The Evening Office is shorter, with preparation; psalm; shorter reading; free prayer and conclusion. I have found Prayers of Great Traditions to be excellent in three settings: for my own personal devotions, for encouraging others to pray during church prayer weeks; and in writing intercessions for church services. This is an excellent resource that will not so much be on your bookshelf as often in your hand.

\section{Oden, T. C. (2012-2014). John Wesley's Teachings (4 Volumes). Grand Rapids: Zondervan.}

I have found Oden's four volume series on John Wesley's teachings to be excellent devotional reading, as well as providing much useful material for sermon preparation. The four volumes are arranged thematically and tackle God and providence; Christ and salvation; pastoral theology; and ethics and society. Each volume is subdivided into thematic parts, further divided in chapters and then sections within those chapters. It has taken me many months to work my way through all of them, but this has been a journey to savour. Oden has skilfully woven Wesley's own words together with his explanations to produce text that is easy to read, yet clear and challenging in its evangelical convictions.

I am not writing this review as a specialist in Wesley studies, but rather as a pastor who has found much spiritual nourishment in this series. Occasionally Oden offers his own views on the subject under discussion, but most of the time he simply lets Wesley speak for himself. 
What comes across is that Wesley was a powerful and passionate preacher, fully committed to proclaiming Christ crucified and resurrected. Wesley's concern for pastoring individuals and congregations, his loyalty to the Anglican Church despite frustration with its failings were things that both encouraged and challenged me as I read. Much of what he says speaks into our contemporary situation with a clarity that may surprise some readers. I do not think I would ever have sat down to read all of Wesley's letters and sermons, but having read these volumes I will certainly find some of them to read in greater detail. Wesley was a gifted communicator, and Oden has done a masterful job of summarising the core of his teachings. Yet these are not simple topics and these books do demand careful attention. If you are looking for some challenging devotional reading, then I would thoroughly recommend you invest in this series.

Tom Wilson

Anvil Reviews Editor

Cottrell, S., Croft, S., Atwell, R., Gooder, P. (2014). Pilgrim: A Course for the Christian Journey. London: Church House Publishing.

Pilgrim: a course for the thinking Anglican. Now, I know that's not the official sub-title, which is 'a course for the Christian journey,' but I think mine is a more accurate Ronseal type label. That's to say, it helps you know exactly what is in the tin. Pilgrim is a great course with many strengths, but from my perspective also a few weaknesses, many of which could be easily addressed as the course continues to be developed.

For those who are unfamiliar, Pilgrim is a series of eight courses currently being produced by Church House publishing. Four have been published in the 'follow' stage, which cover the Baptismal Promises; the Lord's Prayer; the Commandments; and the Beatitudes. Four in the 'grow' stage, which discuss the Creeds; the Eucharist; the Bible; and Church and Kingdom are forthcoming. Each of the courses in the 'follow' stage has six sessions. This fits very well with some topics. So the set on the Baptismal Promises follows this order:

1. Do you turn to Christ?

2. Do you believe and trust in God the Father?

3. Do you believe and trust in his Son Jesus Christ?

4. Do you believe in the Holy Spirit?

5. Do you repent of your sins?

6. Do you renounce evil?

Those who know the questions well will recognise the reordering, which I presume is to facilitate group discussion, saving the more personal and probing questions for the final two weeks.

Other courses require a certain reworking: the series on the Commandments follows six themes: priorities; reverence; rest; respect; righteousness; and reliability. The first session 
on priorities examines Jesus' summary of the law, and the remaining five sessions each tackle two commandments in turn. Similarly, the series on the Beatitudes has four sessions looking at two beatitudes each, and then two sessions looking at Jesus' teaching about living as citizens of the Kingdom of God.

Each session in each course is structured in the same way. The session begins with responsive liturgy, and ends with a set prayer. In between there is a short Bible reading and questions, together with two short reflections to stimulate discussion. The session ends with a 'sending out' section, which contains a suggested topic for reflection, together with various quotes from Christians down the ages for group participants to consider in the week following the session. Each session has an accompanying short film, available on the website (http://www.pilgrimcourse.org/audio-and-video). Audio versions of the reflections are also available on the web. Although the films were a useful prompt for discussion, personally 1 would have found it more helpful if the films were available on a DVD. It is much easier to show films to a small group on a TV than a laptop, given the hassle of setting up a projector and speakers. Hopefully this can be rectified for future courses. Given the films have already been produced, the production costs of making a DVD are so small, I cannot believe it would be an expensive thing to do.

Although I have looked at all four courses in the 'follow' stage, this review is based primarily on my experience in using two Pilgrim courses, on the Baptismal Promises and the Lord's Prayer, in three contexts. These contexts were: an established Bible study group of older ladies and an enquirers group, both run at church, as well as a work-place Christian Union. The groups thus had very different composition and structure, and so the material was used in a different way in each of them.

Each group had a very different experience of Pilgrim, but there were some common threads. All the groups enjoyed the course overall. The material seemed to work well both with those exploring the Christian faith and also with those who had been Christians for decades. What was especially striking was that in the workplace $\mathrm{CU}$, where there are people of widely varying levels of Christian experience, discussions were wide-ranging and honest. All the groups commented favourably on the quotations in the 'sending out' section. I produced single page hand-outs for each session, rather than expect participants to buy personal copies of the booklets for themselves, and a number of course participants commented that they were using them between sessions to think further about the topics covered.

The main challenge I faced in leading Pilgrim sessions was the fact that the Bible passage is accessed via lectio divina, which was problematic for each group in different ways. For the workplace $\mathrm{CU}$, time pressure (and the fact that people kept arriving throughout the first ten minutes of the thirty minute session) precluded this approach to reading the Bible. The established Bible study group simply could not cope with the change in style, and the 
enquirers group was very small and found the silence followed by sudden pressure to speak uncomfortable. However much I tried to avoid it, in a small group inviting people to speak inevitably created some sense of pressure. I therefore quickly moved away from using lectio divina to simply reading the Bible passage through and then inviting comments and questions before moving on to the reflection and discussion, a strategy which was much more effective for encouraging participants to engage with the Bible.

My only slight disappointment with the course was the videos. Overall, they were impressive and a helpful for bringing a range of perspectives they brought to the different topics under discussion. There was a good mix of speakers, with a range of ages and professions represented. I had two minor concerns. One was that the clergy were all identified very precisely, but everyone else very generally. So we learnt that one individual was the Bishop of Stockport, while another was simply a teacher. There are two issues with this. First, by the time we were watching the video, Robert Atwell had been announced as the new Bishop of Exeter, so the information was wrong. Second, why does it matter where he is Bishop of? Or even that he is a Bishop at all? If job descriptions are to be given, then they should give equal information about all people. My second concern came from the video in the week 'Do you believe in the Holy Spirit?' The five other videos in the Turning to Christ course were all about 5 minutes of different views being shared. Yet half of this one was a reading of Psalm 8. Does the Church of England really have so little to say about the Holy Spirit that an extra Psalm had to be included in the video to pad it out? Perhaps I am being overly critical, but I was disappointed that more was not said about the Fruit of the Spirit growing in individual's lives, or learning to listen to how the Spirit informs our consciences and guides us towards more godly living. I was not bothered that the more charismatic gifts were not discussed in detail: those who want that information could easily obtain it. But there was so much more that could have been said.

These are, of course, relatively minor concerns, but ones I do think it would be helpful to have addressed as the rest of the course is produced. Overall, Pilgrim is a very solid resource, all the stronger for being produced by a team than by a sole author. The range of perspectives brought to each subject enriches the study. Even within each course wide range of scripture is covered, and if all four courses were covered, then participants would be exposed to a wide range of texts, and so hopefully increase in their Biblical literacy.

I recently attended a Clergy training day led by Steven Croft, Bishop of Sheffield and one of the principal authors of the Pilgrim series of courses. He was asked about which evangelistic resources he recommended, and told us that research suggested the most effective courses are home grown ones. We then had a coffee break, and immediately following that break we had a session in which he extolled the virtues of Pilgrim and encouraged us to buy the resources. The irony was not lost on me, and I suggest following Bishop Steven's advice when engaging with Pilgrim. There is some great material here. The overall shape of the sessions is very clear. The questions do prompt good discussions and there is much food for 
thought, much to help Christian pilgrims on their journey of faith (to use the phraseology of the course itself). But bespoke is always better fitting that off the peg, and this course is no different. Shape it, adjust it, make it your own, and use it to encourage others to follow in the way of Christ.

Tom Wilson

Anvil Reviews Editor

\section{Biblical Studies}

Briones, D. E. (2013). Paul's Financial Policy: A Socio-Theological Approach. London: Bloomsbury.

Paul's Financial Policy is based on David Briones' recent PhD, in which he explores the question of why Paul accepted financial help from the Philippians, but not from the Corinthians. Briones reviews past approaches and argues for a socio-theological approach taking account of patron-client relationships and expectations in gift-exchange.

Briones argues that Paul accepts help from the Philippians (after his departure) because the Philippian congregation have a full and trusting koเvwvi $\alpha$ (partnership/ fellowship) with him. This relationship was positive and reciprocal and involved kotvwvi $\alpha$ in gift (Phil 4.15) and suffering (Phil 4.14) $(69,115-116)$. Briones shows that in the relationship between the Philippians and Paul, God's grace is ministered by each party to the other and God is the benefactor. This can be seen in the way Paul writes to the Philippians, having received their gift. Paul builds on the Graeco-Roman expectations of gift-exchange; he 'works from within this two-way relationship and reshapes it from the inside-out by creating a three-way pattern of exchange, one which envisions God as the source of the gift, the Philippians as the mediator or broker, and Paul as the beneficiary' (104).

Briones argues that Paul does not accept help from the Corinthians because he did not have the same kind of kolvwvi $\alpha$ with them and they did not see the three-way movement of grace. Rather 'the Corinthian church embodied the social values of Corinthian society rather than the values of the divine economy' (148). Therefore they 'repressed the divine momentum of $\chi \alpha$ ós [grace]' (150). Paul's response to the Corinthians is to point out their spiritual immaturity, God as the source of all grace, Paul as a mediator of grace the Corinthians as 'unworthy' recipients of grace (150-157).

While Briones agrees that there is a patron-client background to Paul's relationship with the Corinthians, he argues against the consensus view that the Corinthians want to be Paul's patron. He argues instead that Paul would be in the superior position as teacher as he had the knowledge that the Corinthians would want to gain. However, Briones' argument does not seem to take into account that while pupils could be expected to show loyalty to teachers, this was usually in the context of teachers of children or young people, and the 
teacher would have had a different relationship with the pupils' parents. In addition Dio Chrysostom (Or. 77/78.34) and Tacitus (Ann. 16.32) provide evidence that points to those teaching/ philosophizing becoming clients rather than patrons. However Briones' argument that Paul is willing to receive financial help from congregations when they see themselves as part of a three way koıvwvi $\alpha$ and movement of grace does not depend on the Corinthians wanting to be Paul's client.

Briones provides a thoughtful and helpful contribution to the question of Paul's policy about financial assistance. His work is particularly helpful in articulating the three-way approach, and the place of koเvwvi $\alpha$ and grace.

Fiona Gregson

Birmingham

\section{Brueggemann, W. (2014). Reality, Grief, Hope: Three Urgent Prophetic Tasks. Grand Rapids: Eerdmans.}

In Reality, Grief, Hope Walter Brueggemann draws 'dynamic analogies' between two situations of dislocation and crisis: Israel after the disaster of $587 \mathrm{BC}$ when the Babylonian empire invaded Judah, sacked Jerusalem, destroyed the Temple and took the leading citizens into exile; and the situation of the US in the aftermath of the 9/11 attacks. Brueggemann sees these cataclysmic events as signs of the failure of the ruling ideologies of their respective societies. The official Jerusalem-centred, royal-sponsored 'ideology of chosenness' (5) of sixth century Judea was completely undermined by the events of 587. Similarly the $9 / 11$ attacks on the US mainland pose a challenge to the ideology of exceptionalism' (2) which dominates US society and its churches.

The prophets of the exilic period, Jeremiah, Ezekiel and Deutero-Isaiah, confronted the people with the reality that the city, temple and dynasty which were believed to be eternally underwritten by God had come to an end. Prophets speak to society because they are grounded in the reality of sovereign God and not in society's myths and propaganda. Only when reality has been accepted can the necessary work of grieving happen and only then can a new and unexpected word of God break in with hope.

Some Evangelicals will have problems with Brueggemann's historical and literary assumptions in his approach to the text and his use of Marxist social and economic theories (probably more of a problem in the US than in Britain). However his central argument about the role of the prophets confronting injustice and self-deception in the sixth century $B C$ stands. What is more controversial are the analogies he draws with American society. He portrays the US as an empire whose wealth and privilege are based upon economic exploitation, the silencing of voices 'from below,' and military might. He argues that the 'ideology of exceptionalism' with its sense of privilege and entitlement is a distorted view of the world which prevents its citizens from seeing the cost of US dominance, borne by the 
poorest in the US and the poorest nations of the world. He argues that its policies leave the US vulnerable, and that the events of 9/11 are a 'wake-up call' (33) to those who are living an illusion. Brueggemann calls upon the churches to confront society with reality, however unpalatable, for only then will it be able to hear God's new word.

Reality, Grief, Hope is strongest in exposing the dominant ideology of the US and the dynamic analogy which Brueggemann draws between this and sixth century Judah is illuminating. It is a refreshing and challenging read. It has direct relevance to the American churches, however his call on the church to be a prophetic voice and to live a prophetic life is a challenge to the churches in Britain. Britain may not hold an explicit ideology of exceptionalism, but we are a part of the global capitalist 'empire' centred on the US and we have in part assumed a similar sense of privilege and entitlement within the global market which has unseen and unacknowledged victims.

Brueggemann's call to the contemporary church to learn from the prophets and to engage with the dominant ideologies of our day in a way that is founded upon a belief in the sovereignty of God is one that challenges all who are concerned with the church's engagement with our post-Christendom consumer society. This is a challenging and hopeful book - hopeful rather than optimistic - because hope for Brueggemann, like the prophets who inspire him, is found in God who speaks into our denials and self-deceptions.

Tim Gill

Liverpool

Bryan, C. (2014). Listening to the Bible: The Art of Faithful Biblical Interpretation. Oxford: Oxford University Press.

This short essay by a theologian (not known to me) with an English Literature background makes for interesting reading. It would seem that he originates from the UK but has taught in the USA for many years, hence some allusions which are unknown this side of the Atlantic. He notes that biblical texts were a preparation for utterance (114), and describes his hermeneutic as 'participatory exegesis' (127) by which he means that the Scripture is meant to be read and interpreted within a believing community.

There are issues where I would disagree but I am warmed by his insistence on the Bible being read thoughtfully and with intelligence, that is to say, one is grasped by what is being read and thus I would say is 'inside' the text. So often in evangelical circles we pray for the Spirit to work through the preaching but less so about His working through the reading of the Scripture. So often it is obvious that the reader has only a hazy understanding of what she is saying. 
The book ends with an appendix by David Landon with practical exercises on how to read the text and help others to make sense of it and be gripped by it. A book with many useful ideas and some good help for the reading of the Scripture.

Peter Ballantine

Milton Keynes

\section{Carson, D. ed., (2013). The Scriptures Testify About Me: Jesus and the Gospel in the Old Testament. Downers Grove: Inter-Varsity Press.}

This book is a collection of plenary talks given at The Gospel Coalition National Conference in April 2011. The Coalition, originating in informal conversations in 2004 between D.A. Carson and Tim Keller, is 'a fellowship of evangelical churches deeply committed to renewing our faith in the gospel of Christ and to reforming our ministry practices to conform fully to the Scriptures.' It positions itself as seeking to occupy 'the central ground between obscurantism and liberalism' (quotations from the website, accessed January 3rd 2014). Although having a global impact through its website and the ministry of its fellowship, it is largely a North American organisation. Only one of the eight authors is based outside the USA (Conrad Mbewe, from Zambia).

The theme of the conference that spawned this book was 'They Testify about Me: Preaching Jesus and the Gospel from the Old Testament.' The initial explanatory preface by D.A. Carson is followed by eight chapters. In the preface, Carson explains the nature of the book - not to provide a 'manual on "how to read the Old Testament in the light of the New"' but, with the exception of the first chapter, to 'offer ... some examples of Christian preachers handling a variety of highly diverse Old Testament texts.'

The first chapter, by R. Albert Mohler, Jr., 'Studying the Scriptures and Finding Jesus' is the closest to a methodological chapter. Even here, though, it is not a handbook of how but an exhortation, rooted in an exposition of John 5:31-47, of the need to recognise and preach Christ in all the Scriptures. His exegesis of John 5:39-40 leads him to declare, 'We do not look to the Old Testament merely to find the background for Christ and his ministry, not even for references that anticipate him. We must find Christ in the Old Testament - not here and there but everywhere' (19). He identifies a number of contemporary ways of dismissing the Old Testament, but thinks the biggest problem is ignorance and neglect. He reserves his harshest words for moralizing evangelical preaching. He cites recent studies as confirming that young Americans are leaving the church in droves because their theology is too often 'moralistic therapeutic deism'; moralistic preaching reinforces this. The antidote is the primacy of a redemptive-historical hermeneutic in reading and preaching the Old Testament.

The remaining seven chapters consist of seven talks on different Old Testament texts. Chapter 2, 'Getting Out' by Tim Keller, is an exposition of Exodus 14. He notes the striking continuities between the exodus from Egypt and the exodus of the Christian from sin and death. There are some penetrating insights on objectively being free but subjectively feeling 
still in slavery; but there is also a danger that the Old Testament exodus is reduced to a mere visual aid to spiritual slavery.

In chapter 3, 'From a Foreigner to King Jesus,' Alistair Begg makes some prefatory comments about preaching Christ from the Old Testament, covering challenges, assumptions and observations. I particularly appreciated the analogy of finding a river's tributaries by starting at the mouth of the river for why it is easier to read the Bible backwards, starting with the New. The bulk of the chapter expounds the book of Ruth. He gives 'three charcoal sketches' and makes connections with Christ. This is rather different from 'finding' Christ in Ruth.

In chapter 4, 'When You Don't Know What to Do,' James MacDonald unpacks Psalm 25, working verse by verse. Throughout, he encourages the connection between the Psalmist and the believer. The Christological dimension emerges at the end. For him, Jesus is 'everywhere' in the Psalm, for he embodies (that is, is the object of), enables and exemplifies my trust.

In chapter 5, 'The Righteous Branch,' Conrad Mbewe expounds Jeremiah 23:1-8. For him, the person 'referred to' is the same as the one in Isaiah 53 (Jesus); the period Jeremiah is 'referring to' in 23:7-8 is the day when Jesus returns to 'wrap up history.' Those statements about referents are less nuanced than to say, as he does elsewhere, that 'only Jesus fully satisfied the description that Jeremiah gave us.'

Chapter 6 is Matt Chandler's exposition of Ecclesiastes 11:9-12:8. This chiefly is a high-level biblical-theological appropriation/re-reading of the imperatives of 11:9 (rejoice) and 12:1 (remember), which 'lead us to Christ.' Perhaps more accurate is to say that these imperatives are read in the light of Christ.

Chapter 7, "God's Great Heart of Love toward His Own," by Mike Bullmore, is an exposition of Zephaniah. It highlights 'progressive revelation' and stays largely in the text of Zephaniah, noting the paradigmatic movement from the certainty of judgement for sin to a glimmer of hope (2:1-3) then to 'bursting into rejoicing' (3:14-17). Zephaniah has a gospel pattern, and God taking away judgements against them (3:15) is 'a beautiful statement of the heart of the gospel.' The way in which the 'Old Testament is pregnant with the gospel of Jesus Christ' is that it is 'pregnant with the message of the Bible.'

In the final chapter, D.A. Carson expounds Psalm 110, 'Getting Excited about Melchizedek.' Carson initially argues that the Psalm's author is David, a conclusion demanded by the superscription and by Jesus' logic in his quotations of the Psalm. David's reference to Melchizedek arose from his reflections on Genesis 14 and his entry into Jerusalem (Melchizedek was king of Salem - Jerusalem). He realised that monarchy could, one day, be combined with priesthood despite the law's proscription and his predecessor Saul's ill- 
conceived attempt to do so. Finally, Carson unpacks Hebrews 7, arguing that its author reads the Old Testament carefully and responsibly in identifying Jesus as the true priest-king.

Alongside the diversity of texts handled, there is also a variety of approach and, I suspect, view as to how Christ is 'found' in the Old Testament. Not everyone will agree with all the arguments or methods. But as a stimulating dialogue partner for ministers, theological students and interested others, the book serves its purpose.

James Robson

Wycliffe Hall, University of Oxford

\section{Clines, D. (2011). Word Biblical Commentary 18B: Job 38-42. Waco: Word.}

This volume is the final volume in a series of three written by David Clines on the Book of Job. This volume concentrates entirely on the Lord's answer to Job out of the storm and the end of Job's story. Clines brings to bear his extraordinary depth of knowledge in the area of Hebrew language and literature as he grapples with the difficult areas of text. The discussion is extremely helpful for questions of exegesis and handling the text. The indices:

'Emendations, re-arrangement and "New Words"', 'Classified Index' and 'Index of Hebrew Words' will be of interest and great help to those who want to study the text in greater detail. The highly detailed bibliographies (helpfully divided by chapters of the Book of Job and then by areas of study) are a one-stop shop for further reading on the Book of Job. Of particular and increasing interest to many people will be the section on Job in art, music, dance, film, bibliodrama, liturgy, sermons, psychology and even botany.

By any standards this is a work of superlative scholarship and to be valued as such. By the very degree of commitment and passion which Clines brings to his engagement with the text he draws the reader into the drama and the depth of yearning in Job as he seeks for answers. In places I disagreed with Clines' comment at the hermeneutical level: his interpretation of the intention behind certain speeches. For example, Clines himself acknowledges the ambiguity of Job's final speech in 40:6. Does Job repent or accept consolation? Traditionally it has been interpreted as the former but the latter is entirely possible, hence 'So I submit, and I accept consolation for my dust and ashes' (Clines' translation). Clines builds from this reading a carefully constructed argument that Job withdraws his case against God because he knows that God has dismissed his lawsuit and will not answer it. So Job accepts he cannot be vindicated and, feeling he has nothing more to gain from the encounter, accepts such consolation as he can find. A usefully challenging reading, certainly, but rather too much like a failed hero from Sartre who bids defiance to the heavens and then, unable to sustain the confrontation, seeks to find authentication in the day-to-day.

This book will be of huge benefit for people interested in a committed engagement with a biblical text. Even if the reader does not entirely agree with Clines' conclusions, his 
discussion will stimulate the reader to thinking harder. Those looking for easy, pat answers to the question of suffering and justice will be disappointed: in that respect, Clines' commentary and the Book of Job have a great deal in common.

Jenni Williams

Wycliffe Hall, University of Oxford

\section{Moyise, S. (2013). T\&T Clark Approaches to Biblical Studies: Introduction to Biblical Studies (3rd edition). London: Bloomsbury.}

This is the third edition of a book giving in nine concise chapters an introduction to biblical studies. It has three main changes from the second edition (2004). First, in the chapter on sources, there are added sections on Isaiah, Daniel and constructing an Old Testament timeline; second, there is a short new section on dating the New Testament; finally, the Further Reading at the end of each chapter has been updated.

The opening chapter, God and the Bible, looks at two main topics: what the Bible can give us (or do for us), and how inspiration can be understood. He observes two poles - those that so emphasise the 'divine' side that certain things cannot be true, and those that emphasise the 'humanness' in such a way that can be equally dogmatic. Moyise makes the important clarificatory comment that his subsequent chapters treat different approaches sympathetically, without necessarily endorsing them in toto. Each approach has something to contribute, so repays understanding.

Chapters 2-5 focus on historical approaches. Chapter 2 explores the search for sources, covering Pentateuchal criticism (including Wellhausen's JEDP), Isaiah, Daniel, Gospel criticism and the quest for the historical Jesus. Alongside the lucid analysis that characterises the chapter is a somewhat out-of-place critique of the reading of Genesis 2-3 which promotes 'subservient' roles for women. It is unclear clear why or how source criticism helps that critique (although revisiting the issue in later chapters makes this a helpful case-study). Chapter 3 looks at three different approaches taken in an effort to identify the context or tradition history of the material: history of religions, which looks at comparative material; form-criticism, focusing on the Psalms and the Gospels, and social-scientific criticism. Chapter 4 turns attention to redaction criticism, the question of authorial intention discernible in the shaping of source material. Case studies are Luke's changes to Mark, with a brief exploration of Conzelmann's proposal that Luke altered Mark's depiction of Jesus to deal with the delay in the Parousia, and Matthew's changes to Mark. Finally, he looks at how Mark's and John's intentions might be seen. Chapter 5 turns attention to the text of the Bible, and the question of manuscripts. Discussing New Testament manuscripts, Moyise notes how translations have been shaped by available manuscripts, whether Byzantine from the middle ages, Uncial (capitals), such as Vaticanus, discovered later but dating from C4th5th CE, or papyrus, found later still, but dating from as early as C2nd CE. There follows a brief exploration of the Old Testament text, including the Masoretic Text, early Greek translations 
and the findings at Qumran. The final section of the chapter covers translation technique. The conclusion makes the important point that 'insight or even revelation' is possible although we do not have original manuscripts and that all Bible translations have a degree of subjective interpretation.

The final four chapters turn attention from what the text meant to what it might mean for contemporary readers. Chapter 6 concentrates on one side of this, how texts affect readers. It examines the process of reading (how a reader's understanding changes), rhetorical criticism (how an author persuades) and how narrative works (why they are effective, plot, irony). Chapter 7 looks more closely at the reader - how the reader's 'background, interests and commitments ... influence their interpretations of texts'. Chapter 8 examines those biblical passages which, in Moyise's words, 'themselves appear to promote sexism, racism and imperialism'. He explores how readers can / should read against the grain, resisting the 'prejudices' of the biblical writers that have intruded upon the text. The final chapter, chapter 9, covers theological interpretation. These approaches generally do not simply wish to wind the clock back to before the Enlightenment, but insist that proper interpretation gives due recognition to the Bible as Scripture. Moyise discusses evangelical, christological, ecclesiocentric, canonical and trinitarian interpretation.

Naturally in a book of this kind, not every example will be equally persuasive, nor will all treatments seem even-handed to every reader. Further, the bibliography could benefit from a more thorough updating. But the commendably broad coverage, economical phrasing, lucid style and sympathetic presentation of viewpoints make this my introduction of choice. Readers who will benefit include theological students and thoughtful laypeople or ministers wanting to (re)acquaint themselves with the world of biblical studies.

James Robson

Wycliffe Hall, University of Oxford

\section{Scott Spencer, F. (2012). Salty Wives, Spirited Mothers, and Savvy Widows: Capable Women of Purpose and Persistence in Luke's Gospel. Grand Rapids: Eerdmans.}

Beginning with a tongue in cheek reference to Elizabeth Schussler Fiorenza's Harvard students who called themselves FBI agents (Feminist Biblical Interpretation), Spencer's book aims at accessibility as well as serious engagement with the biblical text of Luke. He begins from the straight observation that in many ways Luke's Gospel and Acts do not serve the causes of feminism particularly well: women are not adequately voiced in Luke after chapters 1-2. There is in Luke-Acts no significant writing to support women preachers or pastors. However, Spencer argues that there are texts which speak of 'capable women of purpose and persistence.' He also notes that the testimony of the women who witnessed to the resurrection 'confirms the women's priority and probity all along as "apostolic" witnesses.' 
I was encouraged by Spencer's open-eyed approach: rejecting the idea that Luke, and indeed Jesus, were first century feminists and acknowledging from the get-go that there are issues for women in Luke's work. Nothing is more annoying that over-eager attempts to make a Bible text 'women-friendly' without looking at difficult texts. However, on the other side, nothing is more annoying than assuming that a Bible text must be de facto inimical to women's interests. Overall I thought Spencer managed to walk the difficult tightrope of constructive, rigorous feminist engagement well.

Spencer begins with three significant studies already done on Luke: those of Schaberg, Seim and Reid. This contained discussion which will be of huge benefit to students beginning feminist study of Luke. There then follows a discussion of what a hermeneutic of suspicion is and how it can operate. Those who tend to skip methodology chapters should linger: these two chapters are well worth it.

The focussed discussion on texts begins in chapter 3 and covers Mary, Jesus' mother (3), Joanna (4), Mary and Martha (5), the illustrative use of narratives: the widow in Zarephath, the queen of Sheba and Lot's wife (6) and the widow who persists in the face of injustice (7). The final chapter uses Nussbaum's categorisation of the capable wife of Proverbs 31 to recapitulate the Lucan characters he has found. Overall the intertextual engagement with other parts of the Bible (especially in the Mary-Martha discussion, where biblical type scenes are used constructively) is extremely helpful.

Although Spencer's reading strategy is narratological he also makes good use of other approaches such as reception historical and insights from historical contexts. I did not agree with Spencer's observation that there are no significant texts to support women preachers or pastors. However, his exploration of women in Luke's Gospel has much to commend it. This book will work well for people doing theological study rather than as a church resource for home groups. Those who do not have much experience of feminist narrative approaches will find a good example of the genre here. Those familiar with this form of hermeneutics will find a stimulating discussion for further thinking.

Jenni Williams

Wycliffe Hall, University of Oxford

\section{Swain, S. R. (2011). Trinity, Revelation and Reading: A Theological Introduction to the Bible and its Interpretation. London: T\&T Clark.}

Theological interpretation is a rapidly growing area of engagement with Scripture which evangelical scholars are becoming involved with in increasing numbers. The quest to recover a distinctively theological interpretation of Scripture began in earnest in the 1990s. Francis Watson, Stephen Fowl and Kevin Vanhoozer are just three well-known names who have made substantial contributions to this discipline. This approach is nothing less than the recovering of an ancient Christian practice. Biblical hermeneutics (to use the modern 
terminology) was the express concern of such venerable figures as Origen and Augustine. The latter's work 'On Christian Doctrine' is regularly cited in modern theological discourse. The avowed purpose of such endeavour was to enable the reader or hearer of Scripture to encounter God. It will be evident from this that the contemporary concern of theological hermeneutics is not an exclusively evangelical one. Within the conservative evangelical camp itself, one finds a considerable variety of approach whilst maintaining an insistence on the final authority of Scripture. Vanhoozer, for instance has written a series of engaging works which demonstrate a willingness to interact with non-evangelical writers. Indeed, Vanhoozer's evangelical orthodoxy has been questioned by some.

Where, then, does Swain's book belong in the spectrum? Swain claims that his own approach has been 'significantly' influenced by Vanhoozer, but I found little evidence of this other than the basic formal shape of his book, the triple focus of which is 'Trinity, revelation, and reading'. This is curious, since Vanhoozer supervised his doctoral dissertation and indeed commends the book as 'richly satisfying.' However, Swain is explicit that his study is 'an attempt at Reformed ressourcement,' by which he means a retrieval of the theological thought and argumentation of an older confessional dogmatics. It is therefore, I think, fair to say that his most significant nod in the direction of a more modern hermeneutic is to make his starting-point the Trinitarian doctrine of God rather than the traditional doctrine of an inerrant Scripture, which comes second. Swain summarises the thrust of his work as follows: 'The central thesis of this book is that we may best appreciate the theological significance of the Bible and biblical interpretation if we understand these two themes in a Trinitarian covenantal context.'

When it comes to the 'reading' part of his title, Swain characterises this as 'an act of covenant mutuality' and elaborates it over two chapters. In chapter 4 , he deals with 'regeneration, renewal, and the role of the church', which explores the role of the church as the agency for the 'awakening of spiritual organs of perception'. He endorses the ancient principle of 'the rule of faith' as a benchmark for canonical exegesis. Doctrinal preunderstanding enables responsible reading. Chapter 5 examines more precisely 'the shape of interpretation'. This, Swain characterises the four 'phases' of interpretation - prayer, explication, meditation, and application, which constitute one multi-dimensional act.

There is much to admire and benefit from in Swain's lucid and attractive exposition, but overall, I was left wondering what was essentially different in Swain's treatment from (say) a book like Jim Packer's perennially popular Knowing God which treats similar themes from a reformed perspective in a less academic fashion. Despite some reservations, then, this is a worthwhile introduction to contemporary reformed theology and I commend it.

Howard Bigg

Cambridge 
Walton, J.H. (2012). The NIV Application Commentary: Job. Grand Rapids: Zondervan.

The great strength of this commentary lies, as the title indeed suggests, in Walton's hermeneutical approach of immediate application: 'The book is not about Job, his friends, or the Challenger. I have suggested it is about all of us, and ultimately about God' (20). Walton is not constructing his application in the sense of a series of easy-to-use sermon applications but rather the belief that the book of Job teaches us about ourselves and God because 'No one is immune to "dark and stormy nights"' (19). Walton's book contains a wealth of information about the book in its Ancient Near Eastern setting, about issuing of dating and an imagined conversation with the Qoheleth from Ecclesiastes which I found thoughtprovoking.

Each passage for discussion is carefully explored and followed by a section called 'Bridging Contexts' which explores the passage in its immediate setting in the text, then theological issues raised on a broader canvas and finally a significance from the book for teaching. Then follows 'Contemporary Significance' where the story of a woman named Kelly is explored in a conversation with the author. The conversation contains all the absolute honesty of the Book of Job with the perspective of a deeply Christian woman for whom suffering and pain is a part of her life but does not rule it. The great strength of this approach is that a dialogue is set up which offers us an engagement with themes of Job without excluding other conversations.

This commentary will be of huge value to anyone who wants to understand the Book of Job better but also to anyone who is ministering to people in difficult and stormy places. It has both exegetical depth and an open-eyed understanding of the challenges of such a book and such a subject.

Jenni Williams

Wycliffe Hall, University of Oxford

\section{Wright, T. ( 2014). Finding God in the Psalms. Sing, pray, live. London: SPCK.}

As an Anglican priest and bishop, Tom Wright has read, prayed and sung the Psalms for most of his adult life. They have been for him, as they have for many others in his tradition, a mainstay of his personal prayer life and corporate worship. The afterword to the book is entitled 'My life with the Psalms', and it is exactly that; a narrative of how the Psalter has helped Wright make sense, theological sense, of life. This short and readable book is the fruit of his encounter with God through the Psalms.

Early in the book Wright introduces one of his main concerns, worldview, that is, how we see and interpret reality. He rightly notes that one of the problems with commending a real and living faith in a real and living God today is not that most people in our society do not believe in God. The problem is deeper, most people cannot even imagine what it might be like to 
live their lives as if this truly is God's world. In this book he explores how the Psalms envisage time, space and matter as the good creation of God which God, in and through Jesus his Messiah, is in the process of redeeming.

Wright's interest is not simply in the Psalms as the product of ancient Israel and Judah but also in how they were read and prayed in the early Church and how they may be read and prayed by individual Christians and Christian communities today. As we immerse ourselves and our lives in the Psalms, so our worldview, our understanding of reality and above all our imagination is transformed as we encounter God through these ancient songs and hymns.

Wright pleads for a restoration of the Psalms in private prayer and public worship. He argues that they could be a rich resource for contemporary hymn writers, not least on the Evangelical (and I would add Charismatic) wing of the church, taking worship to a deeper place than many modern song-smiths go. He also pleads for a restoration of the full Psalter in the face of current trends, not least among lectionary composers, to omit and edit out those Psalms and parts of Psalms that are deemed to be offensive to our delicate modern tastes.

I enjoyed reading Tom Wright's take on the Psalms, I learned more about their influence on the New Testament and the early Church than I did about the ancient sources of the Psalter that is not a criticism. I have prayed the Psalms every day, morning and evening, for over 25 years; Wright has made them new again. His reflections have added a depth to my understanding of these ancient prayers and thereby to my own prayers.

I would recommend this book to all who pray and read the Bible, particularly those in ministry; I would also recommend it to anyone who writes worship songs.

Tim Gill

Liverpool 